\title{
Methylobacterium, a New Genus of Facultatively Methylotrophic Bacteria
}

\author{
T. E. PATT, G. C. COLE, AND R. S. HANSON \\ Department of Bacteriology, University of Wisconsin, Madison, Wisconsin 53706
}

\begin{abstract}
A new genus and a new species of methane-oxidizing bacteria are described. The colonies produced by these bacteria are pink, circular, and convex with entire margins. Cells are gram negative and are normally found singularly with some rosettes. Negative stains indicate polar flagellation. In thin sections, intracytoplasmic membranes, similar to those described as type II in other methylotrophs, were present when the cells were grown with methane. No such membranes were apparent when the cells were grown with the other carbon and energy sources tested. The serine pathway for formaldehyde incorporation is the pathway of $\mathrm{C}_{1}$ metabolism. The deoxyribonucleic acid base composition is 66 mol\% guanine plus cytosine. Methylobacterium is proposed as the name for this new genus of rod-shaped, methane-oxidizing bacteria. The specific epithet in the name of the type species, Methylobacterium organophilum sp. nov., denotes the preference of this organism for organic carbon and energy sources more complex than methane. The type strain of $M$. organophilum is XX (= ATCC 27886). This bacterium differs from all previously described genera and species of methaneoxidizing bacteria in its ability to utilize a variety of organic substrates with carbon-carbon bonds as sources of carbon and energy. The pathways for methane oxidation and the assimilation of one-carbon units are repressed during growth on complex organic substrates.
\end{abstract}

Methylotrophic bacteria are those bacteria that can grow non-autotrophically using carbon compounds containing one or more carbon atoms but containing no carbon-carbon bonds (1). Methylotrophs are considered obligate if they are capable of utilizing only carbon compounds containing no carbon-carbon bonds (methane, methanol, dimethylether, methylamines, etc.) as sole sources of carbon and energy. Facultative methylotrophs are those organisms that can use compounds containing no carbon-carbon bonds as well as organic substrates with carbon-carbon bonds as sole sources of carbon and energy.

The previously described methane-utilizing bacteria, isolated in pure culture, all have had an obligate requirement for methane, methanol, or dimethylether $(6,11)$ as a source of carbon and energy.

Patt et al. (8) reported the isolation of facultative methane utilizers. These organisms use methane, methanol, sugars, and organic acids as their carbon and energy sources. In this paper, we define the characteristics of, discuss the taxonomic position of, and propose a name for, a previously described methane-oxidizing bacterium, strain XX (8).

\section{MATERIALS AND METHODS}

Bacterial strain. Strain XX was isolated from lake samples, as described previously (8).
Media and growth conditions. The mineral salts medium used contained (per liter of distilled water): $\mathrm{KNO}_{3}, 1 \mathrm{~g} ; \mathrm{MgSO}_{4} \cdot 7 \mathrm{H}_{2} \mathrm{O}, 0.2 \mathrm{~g} ; \mathrm{CaCl}_{2}, 0.02 \mathrm{~g}$; $\mathrm{Na}_{2} \mathrm{HPO}_{4}, 0.23 \mathrm{~g} ; \mathrm{NaH}_{2} \mathrm{PO}_{4}, 0.07 \mathrm{~g} ; \mathrm{FeSO}_{4} \cdot 7 \mathrm{H}_{2} \mathrm{O}, 1$ $\mathrm{mg} ; \quad \mathrm{CuSO}_{4} \cdot 5 \mathrm{H}_{2} \mathrm{O}, \quad 5 \mu \mathrm{g} ; \mathrm{H}_{3} \mathrm{BO}_{3}, \quad 10 \mu \mathrm{g}$; $\mathrm{MnSO}_{4} \cdot 5 \mathrm{H}_{2} \mathrm{O}, 10 \mu \mathrm{g} ; \mathrm{ZnSO}_{4} \cdot 7 \mathrm{H}_{2} \mathrm{O}, 70 \mu \mathrm{g}$; and $\mathrm{MoO}_{3}, 10 \mu \mathrm{g}$. The $\mathrm{pH}$ was adjusted to 6.8. A solid medium was prepared by adding purified agar (Difco) to give a final concentration of $1.2 \%$ (wt/vol).

Carbon and energy sources were added to the mineral salts medium, and the testing of substrates to serve as sole carbon and energy sources was performed as described previously (8).

Cells were prefixed in $0.05 \mathrm{M} N$-2-hydroxyethylpiperazine- $N^{\prime}$-2-ethanesulfonic acid (HEPES)-KOH (pH 6.8)-buffered $2 \%$ glutaraldehyde (wt/vol) for 2 $\mathrm{h}$ at room temperature. The cells were centrifuged and washed with water before being enrobed in $2 \%$ agar. The agar block was cut into $1-\mathrm{mm}$ cubes. Postfixation was performed with unbuffered $1.0 \%$ $\mathrm{KMnO}_{4}(\mathrm{wt} / \mathrm{vol})$ for $2 \mathrm{~h}$ at room temperature.

All preparations were embedded in Spurr epoxy resin (10) after dehydration. Thin sections were cut with a diamond knife on an MT-2 Sorvall microtome, placed on uncoated 300-mesh copper grids, and stained with $2 \%$ aqueous uranyl acetate followed by lead citrate (9).

Cells were negatively stained on 200-mesh Parlodion-carbon grids with a $1.5 \%(\mathrm{wt} / \mathrm{vol})$ aqueous solution of phosphotungstic acid adjusted to $\mathrm{pH} 7.0$ with potassium hydroxide. A Zeiss EM9S electron microscope was used to examine and photograph the specimens.

The procedures for deoxyribonucleic acid (DNA) 
isolation and the determination of the guanine plus cytosine $(\mathrm{G}+\mathrm{C})$ content (by equilibrium $\mathrm{CsCl}$ density gradients) were described previously (8).

Enzyme assays for hydroxypyruvate reductase (EC 1.1.1.29, D-glycerate:nicotinamide adenine dinucleotide [NAD] oxidoreductase), hexulose phosphate synthase (no EC number), and glucose-6phosphate dehydrogenase (EC 1.1.1.49, D-glucose-6phosphate:NADP oxidoreductase) and the enzymes of the tricarboxylic acid cycle were as described previously (8).

\section{RESULTS}

The cells of strain XX are short, fat rods, usually occurring singularly (Fig. 1a), with the dimensions 0.8 to 1.0 by 1.5 to $2.0 \mu \mathrm{m}$. Some rosettes are formed. Cells are motile by a single, polar flagellum. The cells are gram negative, catalase positive, and oxidase positive. Granules of poly- $\beta$-hydroxybutyrate accumulate in the cells.

Surface colonies of strain XX are pink and convex with entire margins. Growth occurs at the expense of methane, methanol, ethanol, tricarboxylic acid cycle intermediates, monoand disaccharides, and nutrient broth (Difco). No growth occurred with propanol, ribose, or methylamine.

Ethane is oxidized by cells but does not serve as a source of carbon and energy.

Ammonium salts, nitrate salts, nitrogen gas, and organic nitrogen can serve as the nitrogen source. Nitrogenase was detected in cells grown on a minimal salts medium without nitrate by the acetylene reduction assay (Patt, unpublished data).

The most characteristic feature of this isolate is the intracytoplasmic membranes present in methane-grown cells (Fig. 1b). The intracytoplasmic membranes are arranged around the periphery of the cell and correspond to type II intracytoplasmic membranes. No such membranes were detected in cells grown in a mineral salts medium with glucose or methanol as the sole source of carbon and energy (Fig. 1c and d).

The repression/induction of intracytoplasmic membrane synthesis correlated with the inducibility of methane oxidation (Patt and Hanson, unpublished data). When strain $\mathrm{XX}$ is grown on methane as its sole carbon and energy source, the cells have the intracytoplasmic membranes, and resting cells will oxidize methane. By transferring strain $\mathrm{XX}$ to any other carbon substrate, the intracytoplasmic membrane synthesis for methane oxidation is repressed. When strain XX was transferred to a minimal salts medium with methane as the sole carbon and energy source, the intracytoplasmic membranes were synthesized, and the cells oxidized methane (Patt and Hanson, unpublished data). An enzyme required for assimilation of one-carbon units, $\mathrm{C}_{1}$ serine transhydroxymethylase, has been found to be synthesized during growth on methane and methanol (7) and absent during growth on succinate or glucose.

The organism contains the enzymes hydroxypyruvate reductase (specific activity, 0.29 to $0.89 \mu \mathrm{mol} / \mathrm{min}$ per $\mathrm{mg}$ of protein) and uses the serine pathway for formaldehyde incorporation. Hexulose phosphate synthase could not be detected. Glucose-6-phosphate dehydrogenase $\left(\mathrm{NADP}^{+}\right.$and $\left.\mathrm{NAD}^{+}\right)$was not detectable in methane-grown cells, although it was present in glucose-grown cells (8). All enzymes of the tricarboxylic acid cycle were present.

The DNA base composition of strain XX was determined to be $66 \mathrm{~mol} \% \mathrm{G}+\mathrm{C}$.

\section{DISCUSSION}

Whittenbury and co-workers $(3,11)$ classified methylotrophs into two types based on intracytoplasmic membrane ultrastructure: type I organisms possess parallel, closely packed bundles of membranes consisting of a number of disk-shaped vesicles found throughout the cell; and type II organisms possess a system of paired membranes running throughout the organism or aggregated at the periphery. With respect to the pathway of reduced $\mathrm{C}_{1}$ assimilation, all type I cells use the hexulose monophosphate pathway for formaldehyde incorporation and all type II cells use the serine pathway for formaldehyde incorporation (5). Strain XX has paired membranes aggregated at the periphery of the cell and uses the serine pathway for formaldehyde incorporation; thus, it is a type II methylotroph.

Several other enzymes of intermediary metabolism also follow the classification by type of intracytoplasmic membrane. Strain XX has a complete tricarboxylic acid cycle and lacks glucose-6-phosphate dehydrogenase when grown on methane, as do all the other type II organisms studied to date $(2,8)$.

It has been suggested (4) that the prefix Methylo- be used with an appropriate morphological term in the naming of bacteria of the type under discussion here. For the nomenclature of the genera of methane-utilizing bacteria, Foster and Davis (4) suggested that Meth$y l o-$ replace Methano- as the prefix in the generic name of methane utilizers to avoid confusing the methane-utilizing and methane-producing bacteria. Whittenbury and co-workers (11) classified the more than 100 methane-utilizing bacteria they isolated into five groups. These five groups of obligate methane utilizers are 

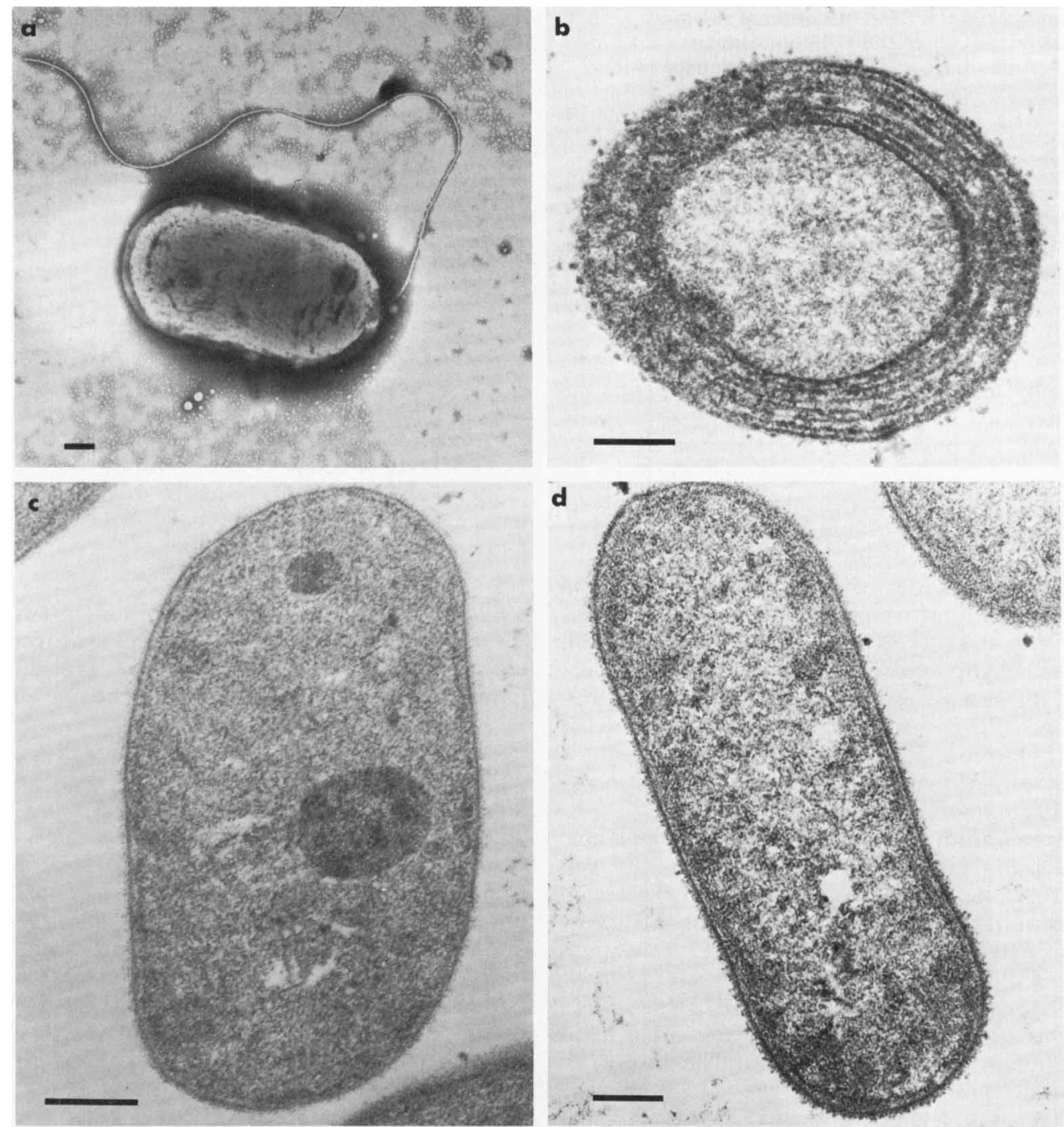

Fig. 1. Electron micrographs of Methylobacterium organophilum strain XX (=ATCC 27886). (a) Negative stain using phosphotungstic acid; (b) thin section of a methane-grown cell; (c) thin section of a glucosegrown cell; (d) thin section of a methanol-grown cell. The bars represent $0.2 \mu \mathrm{m}$.

"Methylosinus," "Methylocytis," "Methylomonas," "Methylococcus," and "Methylobacter." In the eighth edition of Bergey's Manual of Determinative Bacteriology (6), all of the methane-utilizers have been renamed and given the prefix Methylo-. We believe that strain XX belongs to a new genus of facultative methaneutilizing bacteria, for which we propose the name Methylobacterium (Meth.yl.o.bac.te'ri.um. M. L. noun methyl the methyl radical; Gr. noun bakterion a small rod; M. L. neut. noun Methylobacterium methyl bacterium).

The type species of Methylobacterium is $M$. organophilum sp. nov.
A combined generic and specific description follows.

Methylobacterium organophilum gen. nov., sp. nov. (or.gan.o'phil.um. Gr. noun organo organ, living bodies; Gr. adj. philos loving; Gr. adj. organophilus intended to mean preferring complex carbon sources).

Short, fat rods measuring 0.8 to 1.0 by 1.5 to $2.0 \mu \mathrm{m}$. Cells occur most often singularly; some rosettes are formed. Gram negative. Motile by means of a single polar flagellum.

Colony characteristics: Light pink, darkening with age, circular, convex with entire margins. 
DNA base composition: $66 \mathrm{~mol} \% \mathrm{G}+\mathrm{C}$.

Temperature relationship: Optimum, $28 \pm$ $3 \mathrm{C}$.

pH relationship: Optimum, $6.8 \pm 0.2$.

Physiology: Aerobic. Incorporates $\mathrm{C}_{1}$ units by the serine pathway for formaldehyde incorporation and has a complete tricarboxylic acid cycle.

Nutrition: Prefers more complex organic carbon and energy sources to methane. No additional growth factors are required.

Type strain: XX, isolated from sediment from Lake Mendota, Madison, Wis. This strain has been deposited in the American Type Culture Collection (ATCC), Rockville, Md., under the number 27886.

The $\mathrm{G}+\mathrm{C}$ content of strain $\mathrm{XX}$ was determined to be $66 \mathrm{~mol} \%$, compared with $62.5 \mathrm{~mol} \%$ for Methylococcus capsulatus and $52.1 \mathrm{~mol} \%$ for Pseudomonas methanica (4).

The description of the family Methylomonadaceae appearing in the eighth edition of Bergey's Manual of Determinative Bacteriology includes only obligate methylotrophs (6). The proposed genus Methylobacterium is for facultative methylotrophs, but we feel that it belongs in the family Methylomonadaceae rather than in a new family. It shares the properties of growth on methane and methanol, the presence of intracytoplasmic membranes, and a novel pathway for incorporation of $\mathrm{C}_{1}$ units with the other genera in the family.

\section{ACKNOWLEDGMENTS}

This research was supported by the College of Agricultural and Life Sciences, University of Wisconsin, Madison, and by grants from the National Science Foundation (BMS 75-14012) and the University of Wisconsin Graduate School Research Committee. T. E. Patt was supported by Public Health Service training grant 5-T01-GM00686-13 from the National Institute of General Medical Sciences.

\section{REPRINT REQUESTS}

Address reprint requests to: R. S. Hanson, Department of Bacteriology, University of Wisconsin, Madison, Wis. 53706 .

\section{LITERATURE CITED}

1. Colby, J., and L. J. Zatman. 1972. Hexose phosphate synthase and tricarboxylic acid-cycle enzymes in bacterium 4B6, an obligate methylotroph. Biochem. J. 128:1373-1376.

2. Davey, J. F., R. Whittenbury, and J. F. Wilkinson. 1972. The distribution in the methylobacteria of some key enzymes concerned with intermediary metabolism. Arch. Mikrobiol. 87:359-366.

3. Davies, S. L., and R. Whittenbury. 1970. Fine structure of methane and other hydrocarbon-utilizing bacteria. J. Gen. Microbiol. 61:227-232.

4. Foster, J. W., and R. H. Davis. 1966. A methane-dependent coccus, with notes on classification and nomenclature of obligate, methane-utilizing bacteria. J. Bacteriol. 91:1924-1931.

5. Lawrence, A. J., and J. R. Quayle. 1970. Alternate carbon assimilation pathways in methane-utilizing bacteria. J. Gen. Microbiol. 63:371-374.

6. Leadbetter, E. R. 1974. Methylomonadaceae, p. 627629. In R. E. Buchanan and N. E. Gibbons (ed.), Bergey's manual of determinative bacteriology, 8th ed. The Williams and Wilkins Co., Baltimore.

7. O'Connor, M. L., and R. S. Hanson. 1975. Serine transhydroxymethylase isoenzymes from a facultative methylotroph. J. Bacteriol. 124:985-996.

8. Patt, T. E., G. C. Cole, J. Bland, and R. S. Hanson. 1974. Isolation and characterization of bacteria that grow on methane and organic compounds as sole sources of carbon and energy. J. Bacteriol. 120:955964.

9. Reynolds, E. S. 1963 . The use of lead citrate at high $\mathrm{pH}$ as an electron-opaque stain in electron microscopy. $J$. Cell Biol. 17:208-212.

10. Spurr, A. R. 1969. A low-viscosity epoxy resin embedding medium for electron microscopy. J. Ultrastruct. Res. 26:31-43.

11. Whittenbury, R., K. C. Phillips, and J. F. Wilkinson. 1970. Enrichment, isolation and some properties of methane-utilizing bacteria. J. Gen. Microbiol. 61:205-218. 